\title{
THE LIMITS OF ENERGY EFFICIENCY MARKETS IN CLIMATE-CHANGE LAW
}

\author{
Noah M. Sachs
}

This Article examines whether market-based policies, deployed in many areas of environmental law, should be harnessed to promote energy efficiency. Several countries in Europe and Asia have experimented with this new approach to energy efficiency, establishing markets that involve mandatory energy savings targets for firms and inter-firm trading of certificates that represent quantified energy savings. Many analysts contend that these new markets can unlock overlooked opportunities for energy efficiency improvements and could be a critical policy tool for addressing climate change.

After describing the rationale for these new markets and their operation in other countries, this Article concludes that the growing international support for energy efficiency markets is misplaced. I argue that market enthusiasts are overlooking problems of institutional design that complicate and weaken this new application of market principles in environmental law, and I demonstrate that energy efficiency markets face several hurdles that are likely to limit their role in climate change mitigation. The hurdles include accurately verifying energy savings, setting environmentally meaningful savings targets, and preventing what I call energy savings "leakage," in which firms participating in the markets outsource energy intensive parts of their operations to non-regulated firms. These limits of energy efficiency markets call into question long-held assumptions about the superiority of market-based approaches in environmental law.

* Professor, University of Richmond School of Law and Director, Robert R. Merhige, Jr. Center for Environmental Studies. This research was conducted on a Fulbright grant at the National Law School of India, Bangalore, and the author is grateful to the Fulbright program and to the University of Richmond School of Law for ongoing support. Early drafts of this paper were presented at the Fulbright Scholars workshop in Chennai, India, in April 2014 and the IUCN biannual meeting in Tarragona, Spain, in July 2014. Many thanks to John Dernbach, Jim Salzman, David Driesen, Deepa Badrinarayana, Corinna Lain, Michael Gerrard, Margaret Taylor, and Jim Gibson for helpful comments on drafts, and to Ryan Murphy, Viktoriia De Las Casas, and Jack Morgan for valuable research assistance. Contact: nsachs@richmond.edu. 
TABLE OF CONTENTS

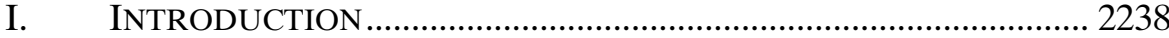

II. DESIGNING TRADING MARKETS FOR ENERGY EFFICIENCY.... 2243

A. The Rationale for Energy Efficiency Markets ...................... 2244

B. Making the Market ................................................................ 2246

1. Determining the Obliged Actors .................................... 2247

2. Defining the Property Right ........................................... 2248

3. Target Setting and Verification ........................................ 2250

4. Creation of a Trading Platform........................................ 2250

III. THE INTERNATIONAL EXPERIENCE WITH ENERGY

EFFICIENCY MARKETS.................................................................. 2252

A. The European Experience with Energy Efficiency

Markets

B. India's Perform Achieve Trade Program ............................. 2255

IV. PROBLEMS OF INSTITUTIONAL DESIGN IN ENERGY

EFFICIENCY MARKETS.

A. The Problem of Ensuring Additionality .............................. 2258

B. The Problem of Setting the Energy Savings Target ............... 2263

C. The Problem of Defining the System Boundary................... 2267

V. CONCLUSION

\section{INTRODUCTION}

Since the 1980s, governments have deployed market-based policies in nearly every area of environmental law: from fisheries management and air pollution control to wetlands protection and greenhouse gas reduction programs. ${ }^{1}$ These policies, which encourage changes in the behavior of firms through price signals rather than through regulatory mandates or pollution limits, ${ }^{2}$ have attracted wide support among policymakers and scholars. As Jody Freeman and Charles Kolstad have explained, "the superiority of market-based instruments has developed into a virtual orthodoxy" in environmental policy circles, and advocates of market-based policies have "capture[d] the high ground in policy debates."3

1. See Carol M. Rose, Environmental Law Grows Up (More or Less), and What Science Can Do to Help, 9 LEWIS \& ClARK L. REv. 273, 282-83 (2005) (describing the shift from "behavior-based" controls on individual firms to market-based approaches); Richard Schmalensee \& Robert Stavins, Lessons Learned from Three Decades of Experience with Cap and Trade (Res. for the Future, Discussion Paper 15-51, 2015), available at http://www.rff.org/files/document/file/RFF-DP-15-51.pdf (discussing market-based approaches to air pollution and greenhouse gas control).

2. Robert N. Stavins \& Bradley W. Whitehead, The Next Generation of Market-Based Environmental Policies 3 (Res. for the Future, Discussion Paper No. 97-10, 1996), available at http:// rff.org/rff/Documents/RFF-DP-97-10.pdf.

3. Jody Freeman \& Charles D. Kolstad, Prescriptive Environmental Regulations Versus MarketBased Incentives, in Moving to Markets in EnVIRONMENTAL Regulation 4-5 (Jody Freeman \& Charles D. Kolstad eds., 2007). 
Energy efficiency policy has long been an exception to this trend. Since the oil crises of the 1970s, energy efficiency law has been dominated by prescriptive government regulations such as minimum performance standards for appliances and minimum average fuel economy standards for cars and trucks, ${ }^{4}$ supplemented by information disclosure requirements such as product labeling. ${ }^{5}$ This traditional approach, though criticized in some quarters for being overly bureaucratic and reducing consumer choice, ${ }^{6}$ has been remarkably effective in saving fuel and reducing greenhouse gas emissions. ${ }^{7}$ In prior work, I argued for an expansion of energy efficiency regulation in the United States. ${ }^{8}$

Improving energy efficiency-that is, reducing the amount of energy consumed to produce the goods and services of modern economiesis one of the most important steps that governments can take to address climate change. ${ }^{9}$ As the United States and governments around the world consider new approaches to energy efficiency, this Article addresses whether market-based policies should replace or supplement the traditional regulatory framework. Could energy savings be quantified, packaged, and traded among firms, just as firms now trade carbon dioxide emissions allowances and fishing quotas? What would we gain by turning energy savings into a tradable commodity? And how would such trading markets contribute to climate change goals?

These questions are not just theoretical, as several governments are already operating energy efficiency markets. France and Italy established such markets a decade ago to reduce electricity and gas consumption, ${ }^{10}$

4. See Noah M. Sachs, Can We Regulate Our Way to Energy Efficiency? Product Standards as Climate Policy, 65 VAND. L. REV. 1631 (2012) (providing an overview of energy efficiency regulations in the United States and the European Union); see also WORLD ENERGY COUNCIL, WORLD ENERGY Perspective: Energy EfFiciency Policies: What Works and What Does Not 45 (2013), avail-

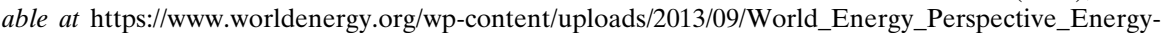
Efficiency-Policies-2013_Full_Report.pdf (describing regulatory approaches to energy efficiency); Mirjam Harmelink et al., Theory-Based Policy Evaluation of 20 Energy Efficiency Instruments, 1 ENERGY EFFICIENCY 131 (2008) (examining policy instruments used in the United States, Europe, and Japan).

5. See Karen Palmer \& Margaret Walls, Can Benchmarking and Disclosure Laws Provide Incentives for Energy Efficiency Improvements in Buildings? (Res. for the Future, Discussion Paper 1509, 2015) available at http://www.rff.org/files/sharepoint/WorkImages/Download/RFF-DP-15-09.pdf.

6. See, e.g., Ted Gayer \& W. Kip Viscusi, Overriding Consumer Preferences with Energy Regulations, 43 J. REG. ECON. 248 (2013).

7. For example, the U.S. Department of Energy estimates that its efficiency regulations issued since 1987 for equipment such as refrigerators and air conditioners will avoid seven billion tons of greenhouse gas emissions through 2030. U.S. DEP'T OF ENERGY, SAVING ENERGY AND MONEY THROUGH APPLIANCE AND EQUIPMENT STANDARDS (2015), available at http://energy.gov/ sites/prod/files/2015/02/f19/equipment_standards_factsheet_updated_Feb_11_2015.pdf.

8. Sachs, supra note 4.

9. MCKinSEY \& CO., ENERGy EFFiCIENCY: A COMPELling Global ResourCe 2 (2010) (noting that energy efficiency represents about forty percent of the greenhouse gas reduction potential that can be achieved for less than sixty euros per ton); John C. Dernbach et al., Energy Efficiency and Conservation: New Legal Tools and Opportunities, NAT. RESOURCES \& ENV'T, Spring 2011, at 7; Noah M. Sachs, Greening Demand: Energy Consumption and U.S. Climate Policy, 19 DuKE EnVTL. L. \& POL'Y F. 295 (2009).

10. For information about France's energy efficiency market, see INT'L ENERGY AGENCY, Market Trends and Medium-Term Prospects, 2013 ENERGY MARKET ReP 142-143, available at http:// www.iea.org/publications/freepublications/publication/EEMR2013_free.pdf. For Italy, see Nathanlie Sabbatucci \& Nicola Labance, Change Best, TASK 2.1: National Report on the 
and India established a market in 2012 to improve industrial energy efficiency. ${ }^{11}$ Although the theory of tradable permits originated in the United States, ${ }^{12}$ the United States has not established a market for energy efficiency, and the markets operating abroad have received little attention here.

The new energy efficiency markets are a legal hybrid. They involve a government-established, mandatory energy savings target for an industry or individual firm, coupled with trading among firms of Energy Savings Certificates ("ESCerts"). ESCerts are government-issued certificates that purport to certify that a firm has achieved a certain amount of energy savings. ${ }^{13}$ In the trading market, firms that can surpass their own energy savings target will become sellers of the ESCerts, while firms that fall short of their target are obligated to purchase ESCerts from the betterperforming firms. In theory, the trading price of the ESCert should provide an incentive for firms to undertake investments in energy efficient equipment and practices that they otherwise would have overlooked. ${ }^{14}$

While few American scholars have studied these markets, international scholarship, written mainly by economists and energy policy analysts, has been enthusiastic, ${ }^{15}$ echoing the broad scholarly support for tradable permit programs in other areas of environmental law. ${ }^{16}$ Scholars have contended that energy efficiency markets create flexibility for firms, provide continuing incentives to save energy, and achieve a given amount of energy savings (or efficiency improvement) at lower cost than traditional, prescriptive approaches to energy efficiency. ${ }^{17}$ They have

ENERGY EFFICIENCY SERVICE BUSINESS IN ITALY 9 (2009), available at http://www.fireitalia.org/prova/wp-content/uploads/2014/04/Task2_1_Italy_Final.pdf.

11. Int'l Energy Agency, supra note 10, at 166.

12. The theory of issuing tradable property rights for pollution control and resource allocation can be traced to Ronald Coase's landmark article, The Problem of Social Cost, and to later work by Baumol and Oates. See R. H. Coase, The Problem of Social Cost, 3 J.L. \& Econ. 1 (1960); William J. Baumol \& Wallace E. Oates, The Use of Standards and Prices for Protection of the Environment, 73 SWED. J. ECON. 42 (1971).

13. Jan Hamrin et al., Ctr. For Resource Solutions, The Potential for Energy SAvings Certificates (ESC) As a Major ToOl in Greenhouse Gas Reduction Programs i (2007).

14. See id. at 5; Edward Vine \& Jan Hamrin, Energy Savings Certificates: A Market-Based Tool for Reducing Greenhouse Gas Emissions, 36 ENERGY POL'Y 467, 468 (2008).

15. See Monique VoOgt et AL., ECOFys, ReVIEW AND ANAlysis of NATIONAL AND REGIONAL CERTIFICATES SCHEMES, http://www.ewc.polimi.it/dl.php?file=Report\%20on \%20 certificate\%20trading\%20schemes.pdf (2014); Ole Langniss \& Barbara Praetorius, How Much Market Do Market-Based Instruments Create? An Analysis for the Case of "White" Certificates, 34 ENERGY POL'Y 200 (2006); Luis Mundaca, Markets for Energy Efficiency: Exploring the Implications of an EUwide 'Tradable White Certificate' Scheme, 30 ENERGY ECON. 3016, 3021 (2008) [hereinafter Mundaca, Markets for Energy Efficiency]; Luis Mundaca, Transaction Costs of Tradable White Certificate Schemes: The Energy Efficiency Commitment as Case Study, 35 ENERGY POL'y 4340, 4340 (2007) [hereinafter Mundaca, Transaction Costs]; Vlasis Oikonomou \& Luis Mundaca, Tradable White Certificate Schemes: What Can We Learn from Tradable Green Certificate Schemes?, 1 ENERGY EFFICIENCY 211, 211 (2008); Vlasis Oikonomou et al., An Ex-Ante Evaluation of a White Certificates Scheme in the Netherlands: A Case Study for the Household Sector, 35 ENERGY POL'Y 1147, 1147 (2007).

16. See Freeman \& Kolstad, supra note 3

17. See PaOlo Bertoldi \& Silvia Rezessy, Inst. FOR EnV'T AND Sustainability, Tradable Certificates for Energy SAVings (White CertificAtes): Theory and Practice 35 (2006), [hereinafter TRADABLE CERTIFICATES] available at http://iet.jrc.ec.europa.eu/energy 
claimed that ESCert markets are a "breakthrough plan"18 that can "unlock energy saving potentials" 19 and serve as a "market-based and credible accounting instrument" to achieve environmental goals. ${ }^{20}$

After reviewing the experience with energy efficiency markets to date, I arrive at a contrary position, one that challenges the use of tradable permits to promote energy efficiency. I conclude that there are persistent, structural weaknesses in the current energy efficiency markets in Europe and India and that these weaknesses reveal overlooked dynamics in tradable permit programs. Advocates of energy efficiency markets are neglecting important issues of institutional design and governance, and my review raises questions about the environmental integrity of the markets, their oversight, and their ability to contribute to climate change mitigation. The transaction costs of energy efficiency markets are high, they are not easily scaled, and they have not appeared to promote technology innovation. While tradable permit programs have been successful in other areas of environmental law, they do not appear to be a good fit for promoting energy efficiency.

Tradable permits appear to falter for energy efficiency because of the need to package energy savings - non-use of a resource - into a tradable commodity. In other environmental markets, participants trade items such as wetland acreage or renewable energy generation that can be directly measured or metered. ${ }^{21}$ But energy efficiency markets lack those direct measures, creating troubling uncertainty about whether the energy savings are real and whether environmental goals are actually being achieved. Because regulated entities can "game" complex ESCert trading systems, resulting in unwarranted credits, windfall profits, and undermining of environmental goals, governments should be cautious about embracing this form of market-oriented environmental policy.

This Article identifies three major problems that undermine these new markets. First, energy efficiency markets struggle to ensure additionality. That is, regulators cannot ensure that the energy savings claimed by firms are real and additional to energy savings that would have occurred in the absence of the programs. Far from being a "break-

efficiency/sites/energyefficiency/files/white_cert_report_2006.pdf; Mundaca, Markets for Energy Efficiency, supra note 15, at 3035; Luis Mundaca \& Lena Neij, A Multi-Criteria Evaluation Framework for Tradable White Certificate Schemes, 37 ENERGY POL'y 4557, 4557-58 (2009); Vine \& Hamrin, supra note 14, at 474-75; LOUIS-GAËTAN GIRAUDET \& DOMINIQUE FINON, WHITE CERTIFICATE SCHEMES: THE STATIC AND DyNAMIC EFFICIENCY OF AN ADAPTIVE POLICY INSTRUMENT 8-10 (Centre International de Recherches sur l' Environnement et le Développement [C.I.R.E.D] Working Paper No. 33-2011, 2011) (Fr.).

18. Lisa Margonelli, Toward an Energy Efficiency Trading System, WASH. PosT (Feb. 9, 2007), http://www.washingtonpost.com/wp-dyn/content/article/2007/02/08/AR2007020801294.html.

19. See EuroWhiteCert Project, White Certificates: Concept And Market EXPERIENCES 1, available at http://ec.europa.eu/energy/intelligent/projects/sites/iee-projects/files/ projects/documents/eurowhitecert_brochure.pdf (last visited Aug. 29, 2016).

20. Vine \& Hamrin, supra note 14 , at 474.

21. See Richard E. Ayres, Expanding the Use of Environmental Trading Programs into New Areas of Environmental Regulation, 18 PACE ENVTL. L. REV. 87, 99-100 \& n.97 (2000) (explaining that wetlands in a trading market can be traded for similar wetlands or for wetlands of the same acreage). 
through plan" to save energy, efficiency markets may merely create "hot air" in energy efficiency, ${ }^{22}$ awarding firms valuable credits for ephemeral energy savings.

Second, I show that the energy savings targets that governments have established for these markets have been unambitious, closely tracking business-as-usual improvements in energy efficiency in the economy. Although nothing would prohibit a nation from setting more ambitious energy savings targets, I discuss a variety of political factors that militate against target stringency and show why lax targets appear to be common in many market-based environmental policies. With lax savings targets in most of the existing programs, the trading prices for ESCerts have remained low, and the programs have not forced significant changes in the behavior of firms.

Finally, I show that energy efficiency markets are prone to what I call energy savings "leakage," similar to the well-known problem of carbon leakage in cap-and-trade programs. ${ }^{23}$ In energy savings leakage, firms participating in an energy efficiency market can outsource energy intensive parts of their operations to non-regulated firms, improving their paper record of energy savings without any actual savings of energy (and associated greenhouse gas emissions) in the jurisdiction.

My skeptical view of energy efficiency markets contributes to a body of literature that questions the assumed superiority of marketoriented approaches in environmental law. ${ }^{24}$ Recent scholarship has highlighted problems involving enforcement, target setting, permit allocation, and strategic gaming in a number of market-oriented environmental programs. ${ }^{25}$ I do not contend that all market-based policies are ineffective. Trading markets have performed well in areas such as air pollution control and wetlands protection. ${ }^{26}$ But it has become clear that trading mar-

22. Hot air refers to emissions credits under the Kyoto Protocol that were granted to countries, primarily in Eastern Europe, whose emissions targets under the treaty were higher than their businessas-usual emissions. Countries earned valuable emissions credits, tradable to other countries, without undertaking substantial domestic emissions reductions under the treaty. See Edwin Woerdman, Hot Air Trading Under the Kyoto Protocol: An Environmental Problem or Not?, 14 European ENVTL L. REV. 71, 72-73 (2005).

23. See, e.g., Daniel A. Farber, Carbon Leakage Versus Policy Diffusion: The Perils and Promise of Subglobal Climate Action, 13 CHI. J. INT'L L. 359 (2013); Bernd G. Janzen, International Trade Law and the "Carbon Leakage" Problem: Are Unilateral U.S. Import Restrictions the Solution?, 8 Sustainable DeV. L. \& POL. 22 (2008).

24. See, e.g., David Driesen, Design, Trading, and Innovation, in MOVING TO MARKETS IN

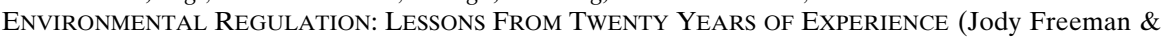
Charles D. Kolstad eds., 2007); Margaret R. Taylor, Innovation Under Cap-and-Trade Programs, 109 PROC. NAT'L ACAD. SCIS. 4804 (Mar. 27, 2012) (concluding that regulated firms actually decreased their research and development investments in pollution control after enactment of cap-and-trade programs because trading prices were lower than expected).

25. See, e.g., Lesley K. McAllister, The Enforcement Challenge in Cap-and-Trade Regulation, 40 ENVTL. L. 1195 (2010); Lesley K. McAllister, The Overallocation Problem of Cap-and-Trade: Moving Toward Stringency, 34 COLUM. J. ENVTL. L. 396 (2009) [hereinafter The Overallocation Problem]; J.B. Ruhl \& James Salzman, Gaming the Past: The Theory and Practice of Historic Baselines in the Administrative State, 64 VAND. L. REV. 1, 46-49 (2011).

26. See, e.g., Nathaniel O. Keohane, Cost Savings From Allowance Trading in the 1990 Clean Air Act: Estimates From a Choice-Based Model, in Moving TO MARKETS IN ENVIRONMENTAL 
kets often fail to achieve their objectives and require far more government oversight and intervention than market advocates recognize. They are simply not the right policy tool for every environmental goal, and they are not the right tool for promoting energy efficiency.

This Article proceeds as follows: in Part II, I provide an overview of ESCert trading and discuss some of the key design choices that governments must make to establish an energy efficiency market. Part II is primarily descriptive and outlines the regulatory framework for the markets. Part III explores the results of the major ESCert programs established to date, focusing on the programs in Europe and India. I show that the European programs have resulted in only modest energy savings and that India's program, while potentially more ambitious in its design, has set lax energy efficiency targets in its early years of operation. Finally, in Part IV, I discuss some of the major problems with ESCert trading. Drawing on economic and legal literature on market-based approaches to environmental law, I demonstrate why the programs are plagued by problems of measurement, verification, and credibility. I conclude that adapting tradable permits to promote energy efficiency is not likely to contribute significantly to climate change goals.

\section{DESIGNING TRADING MARKETS FOR ENERGY EFFICIENCY}

To understand the dynamics of using tradable permits for energy efficiency, it is important to understand the rationale for the markets and how they operate. What are the legal and policy choices that undergird the markets? And why do advocates consider these markets to be a breakthrough for reducing energy consumption? In this Part, I address these questions by discussing energy efficiency markets from the standpoint of institutional design.

I proceed from the proposition, widely shared, that some government intervention is necessary in energy markets. There is a massive literature that explains why markets for electricity, gas, and other fuels, as well as markets for energy efficient equipment, are prone to market barriers and market failures, with the result that firms and households do not adopt energy efficient technologies and practices, even when doing so would be profitable. ${ }^{27}$ This suboptimal investment has been dubbed

REgulation: LESSONS From TwENTY YeARS OF EXPERIENCE (Jody Freeman \& Charles D. Kolstad eds., 2007) (stating that sulfur dioxide allowance trading "has been remarkably successful to date"); Winston Harrington \& Richard D. Morgenstern, International Experience with Competing Approaches to Environmental Policy: Results from Six Paired Cases, in MOVING TO MARKETS IN ENVIRONMENTAL REGULATION: LESSONS FROM TWENTY YEARS OF EXPERIENCE (Jody Freeman \& Charles D. Kolstad eds., 2007) (identifying successful use of market trading in air and water pollution control).

27. See Stephen J. DeCanio, Barriers Within Firms to Energy-Efficient Investments, 21 ENERGY POL'Y 906, 908 (1993); INT'L ENERGY AGENCY, Mind THE GAP: QUANTIFYING PRINCIPAL-AGENT PROBLEMS IN ENERGY EFFICIENCY 11 (2007), available at https://www.iea.org/publications/ freepublications/publication/mind_the_gap.pdf; Thomas Dietz, Narrowing the US Energy Efficiency Gap, 107 PROC. NAT'L ACAD. OF SCIS. 16007, 16007 (2010); Carl C. Koopmans \& Dirk Willern te Velde, Bridging the Energy Efficiency Gap: Using Bottom-up Information in a Top-Down Energy Demand Model, 23 Energy EfFiciency 57, 57 (2001); Adam B. Jaffe \& Robert N. Stavins, The Energy 
the "energy efficiency paradox" or "energy efficiency gap," ${ }^{28}$ and it leads to over-consumption of climate-altering fossil fuels. The academic literature is virtually unanimous in advocating some government action to overcome these market barriers and market failures. ${ }^{29}$ The debate is about which mix of policy tools should be deployed.

\section{A. The Rationale for Energy Efficiency Markets}

The argument in favor of harnessing tradable permits for energy efficiency is that the trading will allow jurisdictions to reach a desired reduction in energy consumption while providing more flexibility to firms (and lower costs) than an equivalent governmental mandate.

Assume, for example, that a jurisdiction aims to reduce energy consumption by eight percent over five years. The government may view this reduction as important for reaching climate change goals or it may simply have few energy resources of its own and wants to reduce fuel imports. Assume further that two firms dominate the energy consumption in the jurisdiction. Firm A can achieve more than an eight percent energy savings in its operations with minor capital investments, while Firm B needs to make significant capital investments to achieve an eight percent savings.

A market in tradable ESCerts would allow Firm A, which has the capability to surpass its target, to sell the resulting ESCerts to Firm B to make up its shortfall, equalizing the marginal cost of compliance between the firms and lowering the overall cost of the program. In some trading markets, non-obligated actors (those that do not themselves have a government-mandated energy savings target) are allowed to participate in the trading markets. ${ }^{30}$ Consider Firm C, a manufacturer that can document energy savings from overhauling an existing process line. Regulators might award an ESCert to Firm C, which can then sell it to Firm B, the larger, underperforming obliged firm in the program.

Paradox and the Diffusion of Conservation Technology, 16 RESOURCE \& ENERGY ECON. 91, 98-99 (1994); John W. Pratt \& Richard J. Zeckhauser, Principals and Agents: An Overview, in PRINCIPALS AND Agents: The Structure OF Business 1, 5 (John W. Pratt \& Richard J. Zeckhauser eds., 1985). Market barriers that hinder investment include lack of access to capital, long payback periods, lack of management attention to energy costs, and search costs. See Jaffe \& Stavins, supra; Michael P. Vandenbergh et al., Individual Carbon Emissions: The Low-Hanging Fruit, 55 UCLA L. REV. 1701, 1755 (2008). Moreover, externalities from energy production and consumption are not fully incorporated into energy prices, leading to market failure. Todd D. Gerarden et al., An Assessment of the EnergyEfficiency Gap and Its Implications for Climate-Change Policy (Nat'l Bureau for Econ. Research, Working Paper No. 20905, 2015), available at http://www.nber.org/papers/w20905.pdf; W. Kip Viscusi et al., Environmentally Responsible Energy Pricing, 15 ENERGY J. 23, 24 (1994) (stating that one potential use of energy taxes is to internalize environmental externalities into energy prices).

28. See Gerarden et al., supra note 27.

29. See supra notes $22,27$.

30. See Robert W. Hahn \& Robert N. Stavins, The Effect of Allowance Allocations on Cap-andTrade System Performance, 54 J.L. \& ECON. 1, 2 (2010). 
ESCert markets are offset markets. ${ }^{31}$ By purchasing an ESCert from another firm that has achieved energy savings elsewhere, a firm can offset a portion of its own energy savings mandate. The ESCert itself is a government-issued certificate (or electronic equivalent) that purports to certify that a firm has achieved a certain amount of energy savings. Typically denominated as savings of megawatt-hours of electricity or savings of tons of oil equivalent ("toe"), ${ }^{32}$ an ESCert is both an accounting tool and a tradable property right with fluctuating value in the marketplace.

There are other policy tools, of course, that might also incentivize firms to reduce energy consumption. The government could raise energy taxes, for example, but energy tax increases are unpopular and regressive. Energy taxes, moreover, provide price signals to firms but cannot guarantee any particular quantity of energy savings, whereas energy efficiency markets are quantity-based instruments that attempt to lock in a particular energy savings goal (or a specific improvement in energy efficiency). ${ }^{33}$

According to advocates, flexibility is one of the most important advantages of the markets. Not only can firms choose whether they want to be buyers or sellers of ESCerts, but those who choose to be sellers can also choose which technological upgrades or changes in production practices they will adopt to conserve energy. ${ }^{34}$ No government agency dictates the exact technologies or practices that firms must adopt.

The ability to package energy savings into a tradable ESCert should, in theory, incentivize investments in energy efficient equipment that might otherwise be overlooked. If a firm concludes, for example, that an investment in highly efficient boilers, motors, or refrigeration equipment has a seven-year pay-back period, the accompanying sale of ESCerts from the energy savings might shorten the pay-back period to five years, motivating the firm to undertake the investment..$^{35}$ In this way, advocates argue, ESCerts can "change mindsets" by making business managers focus on energy efficiency opportunities they may otherwise overlook. ${ }^{36}$

Advocates also point to the scalability of ESCert programs as one of their most attractive features. ${ }^{37}$ While traditional policy tools in energy efficiency aim at particular product categories, such as automobiles or refrigerators, energy efficiency markets might involve whole industries or even entire cities, states, or regions. Indeed, one could envision a system

31. See Tyler McNish, Carbon Offsets Are a Bridge Too Far in the Tradable Property Rights Revolution, 36 HARV. ENVTL. L. REV. 387, 391 (2012) (defining and criticizing offset mechanisms).

32. See Barry Friedman et al., Nat'L Renewable Energy Lab., Considerations for EMERGING MARKETS FOR ENERGY SAVINGS CERTIFICATES 6 (2008).

33. See GIRAUDET \& FinON, supra note 17, at 5 .

34. See Mundaca \& Neij, supra note 17, at 4557 (noting that the program's grant obliged parties "extensive flexibility," which is "crucial because it allows market actors to decide how to meet their targets cost-effectively.").

35. See Margonelli, supra note 18 , at 30 .

36. See, e.g., BERTOLDI \& REZESSY, supra note 17.

37. See id. 
where any actor could locate an energy efficiency improvement, undertake it or fund it, and then "package" the resulting quantified energy savings into an ESCert, tradable to some other party obliged to find savings under the program. The trading could be cross-industry and even crossborder.

In this expansive vision of some market advocates, efficiency markets could be harnessed to reduce energy consumption in industry, residences, commercial and government buildings, and even transportation networks..$^{38}$ Participants in the markets could theoretically include not only major industries, but also millions of small businesses, transportation providers, property owners, and even individuals. ${ }^{39}$ Each would be motivated by the sale price of ESCerts to locate opportunities for energy savings and undertake efficiency improvements in any area of the economy. ${ }^{40}$

Clearly, the expectations for what energy efficiency markets can accomplish are quite high. But this expansive vision - that market trading can unlock otherwise overlooked energy efficiency improvements and thereby significantly reduce energy consumption throughout the economy-is based on a number of assumptions that are not realistic. The vision assumes, for example, that ESCert prices will materially affect firms' investment decisions, that firms in fact have divergent marginal costs to achieve the energy savings target set by the government, and that an ESCert represents actual energy savings that would not have occurred in the absence of the program.

As I detail later in this Article, many of these assumptions are questionable, and the reality of designing and operating these markets on the ground is quite different from the theoretical vision of market proponents.

\section{B. Making the Market}

Creating a trading market for energy efficiency is a multi-step process with numerous challenges of institutional design. Not only must a government create a new property right in quantified energy savings, but it also must monitor and verify the energy savings to ensure that the credits it issues reflect real reductions in energy consumption. Governments must also make a number of preliminary decisions regarding the actors to be obligated under the program and the structure of the mar-

38. See id.

39. European COMmission Intelligent EnERgy Programme, Work Package 3.3., White CertificAtes And InTERACTIONS With Other Policy Instruments 6 (2007) (noting that the energy savings that back an ESCert can "in principle - be realised anywhere"); JOE LOPER ET AL., Energy Savings Credits: Are Potential Benefits Being Realized? Alliance to Save ENERGY 13 (2010) [hereinafter ENERGY SAVINGS CREDITS] (noting that the variety of actors who "could have an interest in developing their own energy efficiency initiatives, earning ESCs for the savings and selling the ESCs to the regulated entities.").

40. Margonelli, supra note 18 (advocating that the United States should create a national energy efficiency market that encompasses utilities and the transportation sector). 
ket.Creating an energy efficiency market usually involves four foundational steps:

\section{Determining the Obliged Actors}

The first step is to determine which industries or firms will become obliged under the program. Two basic market models have emerged. ${ }^{41}$

In the first model, prevalent in Europe, the firms subject to energy savings targets are energy suppliers and/or distributors. They earn ESCerts by performing small-scale, geographically dispersed energy efficiency upgrades in homes and businesses (which tend to underinvest in efficiency on their own). ${ }^{42}$ For example, utilities might subsidize energy efficient thermostats for their customers or assist in the installation of residential insulation. In many countries, utilities have conducted these kinds of efficiency upgrades for decades under utility Demand Side Management ("DSM") obligations. ${ }^{43}$ The ESCert trading markets are touted as a mechanism to aggregate the energy savings achieved in small increments in individual buildings, allowing utilities to reach their DSM obligations at lower cost. ${ }^{44}$

Under the second model, used in India, the firms subject to the energy savings targets are energy end-users, typically large industrial firms in industries such as steel, concrete, and aluminum. ${ }^{45}$ The goal of this market model is industrial energy efficiency improvement, and geographically, the energy efficiency upgrades are highly localized within the fence-lines of particular industrial plants. ${ }^{46}$ Firms are expected to find energy efficiency improvements within their own operations, or they must purchase ESCerts from better-performing firms if they fall short of their target. ${ }^{47}$

There are some clear trade-offs in the choice of obliged parties. Under the first model, only a handful of firms need to be regulated and overseen, and these firms (energy suppliers and distributors) are already subject to some governmental regulation. ${ }^{48}$ The energy suppliers and dis-

41. See Paolo Bertoldi et al., Where to Place the Saving Obligation: Energy End-Users or Suppliers?, 63 ENERGY POL'Y 328, 335-36 (2013) [hereinafter Where to Place the Saving Obligation] (discussing how the choice of obliged parties affects program structure).

42. See id. at 336 ("[R]esidential end-users face additional barriers (technical, market, information etc.) to initiate energy efficiency projects and are often unaware or not interested in the economic benefits involved.").

43. See Edan Rotenberg, Energy Efficiency in Regulated and Deregulated Markets, 24 UCLA J. ENVTL. L. \& POL'Y 259, 265-67 (2006) (discussing different types of DSM measures).

44. See Jan Hamrin et al., Ctr. for Resource Solutions, The Potential for Energy SAVIngs Certificates (ESC) as a Major ToOl in Greenhouse Gas Reduction Programs 2 (2007).

45. Where to Place the Savings Obligation, supra note 41, at 333.

46. Id.

47. Id.

48. In Italy, for example, more than half of the energy savings obligation was placed on a single firm, ENEL, Italy's largest electricity provider. See MiKAEL TOGEBY ET AL., DESIGN OF White CERTIFICATES: COMPARING UK, ITALY, FRANCE, AND DENMARK 17 (2007). Similarly, France placed nearly eighty percent of the required energy savings obligation on two firms, Energie de France and 
tributors act as a leverage point through which the program promotes energy efficiency upgrades in a large number of residential and commercial properties. Because of the geographic breadth of these programs and the number of properties involved, this model for an energy efficiency market tends to incentivize utilities to deploy relatively cheap, off-theshelf technologies capable of mass replication. Utilities may, for example, distribute millions of compact fluorescent light bulbs, upgrade insulation in residences, or replace showerheads ${ }^{49}$ More complicated practices or technologies that might offer greater energy savings, such as changes in building siting or design, tend to get overlooked. ${ }^{50}$

In the second model aimed at industrial energy efficiency, each obliged firm has a direct incentive to improve its own energy efficiency. For example, a steel plant might be given the target of improving the energy efficiency of its own operations by five percent over five years. This market model puts a much wider range of technologies and practices in play to save energy within the confines of individual facilities. To achieve the government-set target, one firm might choose to invest in state-ofthe-art boilers or air conditioning, while another might choose to make changes in its production line or use different raw materials that require less processing on site. Under this model, ESCerts can be traded across industry sectors. An inefficient chemical plant, for example, might purchase ESCerts from a highly efficient steel plant to achieve its target under the program.

While the options to improve energy efficiency within a firm are nearly limitless in this second model, there are also greatly increased transaction costs involved in verifying energy savings in diverse firms throughout an economy, rather than overseeing a handful of energy suppliers and distributers.

\section{Defining the Property Right}

Once the obliged entities are identified, the next step in an ESCert program is to create and define a tradable property right. Energy efficiency markets are often compared to other market-based environmental programs, such as cap-and-trade programs for pollution control or tradable fishing permit schemes, but there is an important difference. In those programs, the property right established by the government is typically a right to emit a certain amount of pollutant or a right to use a certain amount of a natural resource. ${ }^{51}$ The items traded can be metered or measured.

Gas de France. See Eoin Lees, Regulatory Assistance Project, French White Certificates AND ENERgy SAVINGS IN THE TRANSPORT SECTOR 1 (2014), available at www.raponline. org/document/download/id/7159.

49. PaOlo Bertoldi \& Silvia Rezessy, European Commission, Energy Saving Obligations AND TRADABle White CertificATES 25 (2009).

50. Id.

51. See Margherita Colangelo, Creating Property Rights: Law and Regulation of SECONDARY TRAdiNG IN THE EUROPEAN Union 1-32 (2012); see also Carol M. Rose, Expanding the 
The property right for an ESCert program, on the other hand, is unusual. It is a right to own and trade a quantified level of energy savings. The property right accrues to firms that achieve non-use of the valuable resource that the program is trying to conserve. Governments calculate this non-use (and the number of ESCerts to be issued) by comparing the amount of energy the regulated firm actually consumed (or its customers consumed, in the case of utilities) against a hypothetical baseline of energy consumption that would likely have occurred in the absence of the program. ${ }^{52}$

Because of the need to calculate non-use of a resource to define the property right, ESCert programs are far more complex than a typical tradable-permit program. Instead, ESCert markets more closely resemble other offset markets such as the UN's Clean Development Mechanism ("CDM"). The CDM is a prime example of the measurement, verification, and credibility problems that offset markets encounter.

Established under the 1997 Kyoto Protocol, the CDM aims to reduce greenhouse gas emissions from developing countries. ${ }^{53}$ Under the $\mathrm{CDM}$, an Executive Board determines the number of emissions reduction credits that it will award to a project developer by estimating the greenhouse gas emissions from a project over its lifespan (which may be zero in the case of a solar or wind power project) and comparing those emissions to the larger, hypothetical "baseline" emissions (such as those from a fossil-fuel generating plant) that would otherwise have occurred over that same time. ${ }^{54}$ The CDM, like most offset markets, relies heavily on estimation and projections to determine the avoided emissions of greenhouse gases and the resulting amount of credits to be awarded. ${ }^{55}$ The program has been heavily criticized for its inability to ensure that the credits represent true reductions in emissions. ${ }^{56}$ Problems of estimation, measurement, and verification similarly plague energy efficiency markets, and I return to this issue in Part IV.

Choices for the Global Commons: Comparing Newfangled Tradable Allowance Schemes to OldFashioned Common Property Regimes, 10 DuKe EnVTL. L. \& POL'Y F. 45, 51 (1999) (analyzing common property regimes in pollution control and contrasting them with emission trading); Robert N. Stavins, A Meaningful U.S. Cap-and-Trade System to Address Climate Change, 32 HARV. ENVTL. L. REV. 293, 298 (2008) (describing distribution of allowances in a cap-and-trade system); Roy Whitehead, Jr. et al., The Value of Private Water Rights: From A Legal and Economic Perspective, 9 ALB. L. ENVTL. OUTLOOK J. 313, 333-34 (2004) (arguing that tradable fishing permits and transferable quotas, which limit the amount of catch, are preferable to maintaining fish as a common resource). For analysis of allocations of individual fishing quotas, see Dallas DeLuca, One for Me and One for You: An Analysis of the Initial Allocation of Fishing Quotas, 13 N.Y.U. ENVTL. L.J. 723 (2005).

52. For example, in the simplest form of a trading market, if a firm is projected to use $\mathrm{X}$ megawatt-hours of electricity in a given year, and it actually uses the lower amount $\mathrm{Y}$ megawatt-hours, it will be issued ESCerts equal to the difference of X and Y. It can then sell those ESCerts to underperforming firms that were unable to reach their energy savings targets.

53. Christopher Carr \& Flavia Rosembuj, Flexible Mechanisms for Climate Change Compliance: Emission Offset Purchases Under the Clean Development Mechanism, 16 N.Y.U. ENVTL. L.J. 44, 49 (2008).

54. See id. at 49-51; Tom Mounteer, Climate Change Deskbook 25 (2009).

55. See Jonathan Robinson, Climate Change Law: Emissions Trading IN the EU AND THE UK 43 (2007) (noting uncertainties involved in setting baselines).

56. See Carr \& Rosembuj, supra note 53, at 49-51. 


\section{Target Setting and Verification}

Once the property right is defined, the next step in establishing an ESCert program is to set the energy savings or energy efficiency targets for the obliged firms. Setting the target involves an initial decision by the government about whether the program aims to save a fixed amount of energy compared to the status quo or instead aims to improve energy efficiency (energy used per unit of output of a single firm or per unit of GDP).${ }^{57}$ In the latter case, the target may actually allow increases in energy consumption if output is rapidly growing, as in India. ${ }^{58}$

Target setting involves a projection by the regulatory authority of economically feasible energy savings or efficiency improvements - those that are possible using available technology, with reasonable costs for regulated firms. For example, France established a target for its energy efficiency market of 345 terawatt-hours of energy savings between 2011 and $2013 .{ }^{59}$ India set a target of a 5.88\% improvement in efficiency in its steel industry between 2012 and 2015. ${ }^{60}$ Once national or industry-wide savings targets are established, regulators typically allocate the target to individual firms on the basis of market share or other criteria. ${ }^{61}$

Finally, within each program cycle, the regulatory authority must determine whether each firm has surpassed its energy savings or energy efficiency target (and will be issued ESCerts) or has instead fallen short and will become obligated to purchase ESCerts. Governments often impose an additional financial penalty on those firms that have failed to meet their targets.

\section{Creation of a Trading Platform}

There are innumerable ways to structure a trading market once regulators have issued ESCerts to firms. Some countries, such as France and Italy, have established relatively liquid exchanges, with a spot market in certificates. ${ }^{62}$ Others have allowed obliged parties to trade verified energy

57. See GIRAUDET \& FINON, supra note 17 , at 5

58. SANJAy Dube et Al., EMERGENT Ventures InTERnATIONAL, CAN THE LEARNingS FROM

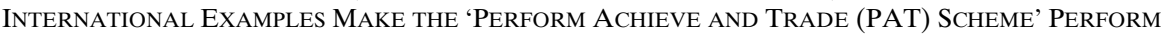
BETTER FOR INDIA 2 (2011).

59. Regulatory Assistance Project, Best Practices in Designing and Implementing ENERGY EFFICIENCY OBLIGATION SCHEMES 49 (June 2012), available at http://www.raponline.org/ event/designing-and-implementing-energy-efficiency-obligation.

60. Abha Shukla, Bureau of Energy Efficiency, Perform, Achieve \& Trade (PAT) (NATIONAL MISSION FOR ENHANCED ENERGY EFFICIENCY) 8, available at http://www.iea.org/ media/workshops/2011/emak-november/1.abhashukla_bee.pdf (last visited Aug. 29, 2016).

61. Regulatory Assistance PROJECT, supra note 59, at 4-5. In establishing an ESCert market, regulators could announce a series of targets and timetables all at once, allowing firms to plan their investments in energy efficiency over a decade or more. Alternatively, governments may set the energy savings targets sequentially, reacting to the trading price of ESCerts and to market conditions. See, e.g., Bertoldi \& Rezessy, EnERgy SAVING Obligations and Tradable White CERTIFICATES, supra note 49, at 8 (noting that "[a]nnual targets give the system administrator the possibility to correct for any implementation flaws.").

62. Luis Alberto Mundaca Toro, Markets for Energy Efficiency: Exploring the New Horizons of Tradable Certificate Schemes 78 (Sept. 2008) (doctoral dissertation, Lund University). 
savings through bilateral contracts, without issuance of certificates. ${ }^{63}$ The ESCerts themselves need to be tracked by regulators so that once a firm uses them for compliance purposes, the certificate is retired and cannot be used again. ${ }^{64}$ Regulators may impose price floors or ceilings to avoid wide fluctuations in the trading price and provide some market certainty to participants. ${ }^{65}$ They may establish specialized exchanges for ESCerts or rely on an existing exchange.

Theoretically, the certified energy savings represented by an ESCert could be converted to a measure of avoided greenhouse gas emissions. Once energy savings are expressed in terms of a fungible unit, such as tons of oil equivalent, it is a straightforward process to convert the energy savings into the number of tons of avoided greenhouse gas emissions. ${ }^{66}$ ESCert markets could then be linked to other, parallel carbon markets, such as the EU's Emissions Trading System. No country has allowed this interlinking of ESCert markets with other markets, however, due to difficulties of monitoring and verification in the ESCert markets.

The four-step process outlined here demonstrates the high degree of governmental involvement that is needed to establish and oversee energy efficiency markets. Although these are ostensibly "market-based" policies, the real work of an ESCert trading market is accomplished by the governmental mandate to reduce energy consumption (or the mandate to improve energy efficiency). The trading market is best viewed as an adjunct to that regulatory mandate, allowing increased flexibility for firms and potentially lowering the cost of compliance. The ESCert trading market, once established, also needs continuing governmental oversight to verify that claimed energy savings have actually occurred.

Advocates of market-based approaches in environmental law tend to underestimate the degree of government standard setting, supervision, and enforcement that is needed to run effective market-based programs ${ }^{67}$ But as is clear from this discussion of the design of an energy ef-

63. The United Kingdom's efficiency program operated under this model from 2002-2012. See Paolo Bertoldi et al., Energy Supplier Obligations and White Certificate Schemes: Comparative Analysis of Experiences in the European Union, 38 ENERGY POL'Y 1455, 1463, 1466 (2010) [hereinafter Energy Supplier Obligations] (stating that during the first two periods, EEC-1 and EEC-2, trading occurred bilaterally, and during the third period, CERT, that ran from 2008 until 2012, energy savings were also traded only between obligated parties).

64. See ENERgy SAVINGS Credits, supra note 39, at 8-9.

65. A price ceiling would limit the risk that ESCert prices would exceed acceptable levels, while a price floor would ensure that there would be some financial incentive for firms to surpass their efficiency targets. Both instruments have been advocated for cap-and-trade programs. See Robert W. Hahn, Climate Policy: Separating Fact from Fantasy, 33 HARV. EnVTL. L. ReV. 557, 579-80 (2009) (suggesting that a price ceiling can be used to mitigate "politically unacceptable price increases," while a price floor can "stimulate innovation in emissions reductions by assuring that greenhouse gas emissions reductions will fetch a positive price."); Peter John Wood \& Frank Jotzo, Price Floors for Emissions Trading, 39 ENERGY POL'Y 1746, 1746-48 (2011).

66. If energy savings are instead expressed in megawatt-hours, some conversion factor would need to be applied (based on the electric generating mix in the jurisdiction) to convert these units into an estimate of avoided greenhouse gas emissions.

67. See David Driesen, Is Emissions Trading an Economic Incentive Program?: Replacing the Command and Control / Economic Incentive Dichotomy, 55 WASH. \& LEE L. REV. 289, 296-311 (1998) [hereinafter Emissions Trading]. 
ficiency market, a strong governmental hand is needed at every stage of the process, and there are substantial transaction costs in the programs. As two scholars concluded with respect to ESCert markets, the programs are "rather demanding with respect to design and operation of the system." 68

\section{THE INTERNATIONAL EXPERIENCE WITH ENERGY EFFICIENCY MARKETS}

With ESCert programs being touted as a next-generation, climatechange-mitigation policy, and with many analysts suggesting that energy efficiency markets should be expanded in the United States, it is important to examine the experience with these markets to date. ${ }^{69}$ In this Part, I assess the major energy efficiency markets that have been established in Europe and in India. ${ }^{70}$ India's Perform Achieve Trade ("PAT") program is still nascent. ${ }^{71}$ Because there is no data on the performance of PAT, my review of the Indian program focuses on some of the regulatory design choices made by Indian regulators in establishing the program.

\section{A. The European Experience with Energy Efficiency Markets}

Energy efficiency markets involving tradable ESCerts (also called "White Certificates" or "White Tags" in Europe) are currently operating in France, Italy, and Denmark. ${ }^{72}$ The United Kingdom operated a form of energy efficiency market, involving bilateral contracts among utilities rather than fully tradable certificates, from 2002 to 2012, but it has now ended the program in favor of a larger package of greenhouse-gasemissions-reductions efforts. $^{73}$

68. Nicola Labanca \& Adriaan Perrels, Editorial: Tradable White Certificates-A Promising but Tricky Policy Instrument, 1 ENERGY EFFICIENCY 233, 234 (2008); see also Vine \& Hamrin, supra note 14 , at 475 (concluding that the "most important issue" with tradable energy efficiency certificates "is the problem of transaction costs").

69. See Labanca \& Perrels, supra note 68, at 235 ("[T] he recent proliferation of certificate-based energy-saving obligation programmes start to provide a growing base of empirical material concerning [certificate] scheme implementation and operation.") (citation omitted).

70. Outside of Europe and India, energy efficiency markets have been established on a small scale by the Australian states of New South Wales and Victoria, and by the U.S. state of Connecticut. For discussion of the Australian programs, see Regina Betz, The Australian Energy Efficiency Schemes, Presentation Held at the European Workshop on Experiences and Policies on Energy Saving Obligations and White Certificates (Jan. 27-28, 2011). For an overview of energy efficiency trading program in New South Wales, see Slobodan Perdan \& Adisa Azapagic, Carbon Trading: Current Schemes and Future Developments, 39 ENERGY POL'Y 6040, 6045 (2011). For discussion of energy efficiency trading program in Connecticut, see Vine \& Hamrin, supra note 14, at 471.

71. Ritu Gupta, Get Ready to Perform, and Then Earn, 1 FIN. VISION 39, 39 (2013); Ragini Bhuyan, Can Market Mechanisms Help India Fight Climate Change?, Live MinT (Apr. 10, 2016), http://www.livemint.com/Politics/nuk1yqmbZLj6foZY1kzh2I/Can-market-mechanisms-help-Indiafight-climate-change.html (describing the results of beginning of ESCert trading).

72. See TOGEBY ET AL., supra note 48 , at 4.

73. Energy Supplier Obligations, supra note 63, at 1463; Where to Place the Saving Obligation, supra note 41 , at 332 . 
While some studies of the energy efficiency markets in Europe have concluded that they have overall net monetary benefits, ${ }^{74}$ it cannot be determined whether those benefits came from the market trading component of these programs or from the underlying governmental mandates to major utilities to reduce energy consumption in their service areas. There is evidence to suggest that the trading component of these programs has not significantly contributed to their environmental goals. In the early years of these programs, for example, the energy savings targets were quite modest, trading volumes were low, and it is clear that the markets had a negligible impact on greenhouse gas emissions. According to a 2009 European Commission study, for example, the energy savings targets adopted by the UK, Italy, and France for their utilities represented only $0.6 \%, 0.3 \%$, and $0.14 \%$ of the total annual energy consumption in those countries, respectively. ${ }^{75}$

Several broad conclusions can be drawn from the European experience with ESCert trading. First, it is clear that the utilities that participate in the programs have been able to reach their energy savings targets fairly easily, which suggests unambitious target setting by the national governments. The European Commission reported, for example, that "over-compliance has been observed in all the existing schemes in the EU, which ... signals unimposing targets in comparison to economic saving potential. ${ }^{.76}$ In France, the two big energy retailers subject to the program were both able to surpass their energy savings targets, achieving $120.7 \%$ of their assigned target at a cost equal to one fifth the penalty had they not achieved it. ${ }^{77}$ Similarly, in the United Kingdom and Italy, nearly all the obliged participants in the program reached or surpassed their savings targets. ${ }^{78}$

Given that the market participants regularly exceeded their energy savings targets on their own, the market trading aspect of the programs was largely superfluous (there were many sellers and few buyers of ESCerts). The underlying energy savings mandates, not market trading,

74. See Mundaca \& Neij, supra note 17, at 4561, 4569 (evaluating emissions trading in Great Britain and observing high energy-saving effectiveness, but cautioning against generalizations or comparative international assertions); Mundaca, Markets for Energy Efficiency, supra note 15, at 3035, 3037-38 (analyzing European trading schemes and whether an EU-wide scheme should be adopted); Oikonomou et al., supra note 15, at 1160-61 (analyzing tradable certificates schemes in Great Britain and Italy, and advocating them for the Netherlands); Vine \& Hamrin, supra note 14, at 469 (stating that the overall energy savings targets for Italy's electricity distribution sector have been achieved).

75. Mundaca \& Neij, supra note 17 , at 4561 .

76. BERTOLDI \& REZESSY, supra note 49 , at 49 .

77. See LEES, supra note 48, at 2. In France, traded certificates represented less than $1 \%$ of all the energy savings mandated in the program. See Where to Place the Saving Obligation, supra note 41, at 329. Trading has been more active in Italy, but only because projects are undertaken by a variety of energy service providers, who then sell the ESCerts to the obliged utilities. See BERTOLDI \& REZESSY, supra note 49 , at 15,23 . One analyst has suggested that the reason trading has been active in Italy is that various energy efficiency equipment installers have been claiming credits for efficiency upgrades in homes and offices that they were performing anyway. See Mundaca \& Neij, supra note 17, at 4562. These installers have then been trading those credits to the obliged utilities. Id.

78. See BERTOLDI \& REZESSY, supra note 49 , at 15. 
drove the participating firms to build or fund energy efficiency upgrades in their service areas.

A second lesson from the European experience is that features designed to reduce transaction costs in energy efficiency markets can have the effect of reducing the ambition of the programs. The European markets rely heavily on an ex ante, "deemed savings" approach to energy measurement and verification. ${ }^{79}$ In this approach, energy regulators simply "deem," or credit, a specified amount of energy savings when electric and gas utilities implement energy-saving techniques for their residential and commercial customers. ${ }^{80}$ This reduces transaction costs because no auditor has to conduct field checks on an ex post basis to measure the actual energy savings. In France, for example, utilities can choose from a menu of over 100 projects listed in the regulations, with associated "deemed" energy savings for each. ${ }^{81}$

As a result of this approach, the European energy efficiency markets have prompted increased spending and deployment of a wide range of off-the-shelf energy efficiency upgrades, such as upgrading insulation or distributing energy efficient light bulbs. ${ }^{82}$ But there is no evidence that ESCert trading has led to transformational improvements in the energy efficiency of products, equipment, or materials. By standardizing the possible energy efficiency upgrades under the programs, governments can reduce transaction costs, but the result is that investments are directed "towards energy savings measures with the lowest cost, thereby deterring investments in projects that may have greater up-front costs, or longer payback periods, but would achieve potentially greater or broader energy savings." 83

A third major lesson from Europe is that ESCert trading makes sense only if firms obliged under the program in fact have varying marginal costs to achieve energy savings. If all firms have nearly identical marginal cost curves, then it makes little sense to enact a tradable permit program. ${ }^{84}$ Yet because the European programs rely heavily on a standardized menu of possible energy efficiency upgrades, the marginal compliance costs of obliged parties are likely to be similar. In the United Kingdom, for example, the participating utilities all hired the same set of subcontractors to make insulation and lighting upgrades in residences, so there was not likely to be a wide variation in their costs. ${ }^{85}$ Of course, we

79. Vine \& Hamrin, supra note 14, at 469-71; BERTOLDI \& REZESSY, supra note 49, at 22.

80. See Vine \& Hamrin, supra note 14 , at 471.

81. Energy Supplier Obligations, supra note 63, at 1461.

82. See id. at 1464 .

83. Vine \& Hamrin, supra note 14 , at 468

84. As Robert Stavins has noted in reference to cap-and-trade programs, "where abatement costs are more uniform across sources, the political costs of enacting an allowance trading program are less likely to be justifiable." Robert Stavins, Market-Based Environmental Policies: What Can We Learn from U.S. Experience (and Related Research)?, in MOVING TO MARKETS IN ENVIRONMENTAL REgulation: LESSONS FROM TWENTY YEARS OF EXPERIENCE 19, 28 (Jody Freeman \& Charles D. Kolstad eds., 2007).

85. See Energy Supplier Obligations, supra note 63, at 1467; Where to Place the Saving Obligation, supra note 41 , at 335 . 
might see more variation in marginal costs if the energy savings targets were more stringent, but as long as the targets are unambitious, the marginal cost of achieving the targets is likely to be uniform across firms.

The European experience suggests that the impact of energy efficiency markets on greenhouse gas emissions is modest. Some analysts have suggested that the programs have had local and regional benefits, such as avoiding construction of new transmission lines and lowering bills for low-income households, but the programs have not appeared to contribute significantly to national and EU-wide climate change goals. Indeed, the European Commission has consistently rejected proposals to institute an EU-wide energy efficiency market, principally because of the difficulty of scaling the markets across national borders. ${ }^{86}$ There would be significant objections, for example, if a French utility could fund energy efficiency upgrades in Sweden and then charge its French ratepayers for the cost. ${ }^{87}$ So after a decade of experience, the new market-based approach to energy efficiency remains confined to a handful of European nations.

\section{B. India's Perform Achieve Trade Program}

India is implementing a different framework for an energy efficiency market, one aimed not at energy suppliers and distributors as in Europe, but rather at energy end-users in the industrial sector. Under India's PAT program, large industrial facilities are expected to achieve efficiency improvements, defined as energy used per unit of output, within their own operations, with the goal of saving energy compared to business-as-usual projections. ${ }^{88}$ This market model differs significantly from the European model and raises its own challenges, particularly regarding estimation and verification of energy savings and transaction costs.

Launched in 2012, PAT establishes energy efficiency targets and an ESCert trading market among 478 separate plants in eight industries: thermal power plants, fertilizer, cement, pulp and paper, textiles, chloralkali, iron and steel, and aluminum. ${ }^{89}$ The program's objective is to improve energy efficiency in the industrial sector, which is the largest sector of energy consumption in India. ${ }^{90}$ Though the eight covered industries

86. BERTOLDI \& REZESSY, supra note 49 , at 50.

87. Id. at 40 (2009) ("The strong local benefits of energy savings projects . . present the major difficulty related to the establishment of a Community-wide white certificate market.").

88. Gupta, supra note 71 , at 39.

89. The firms subject to PAT are concentrated in India's industrial areas of Maharashtra, Rajasthan, Gujarat, and Tamil Nadu. Forty-eight percent of all the plants subject to PAT are located in these four states. $I d$. at 40.

90. India has had various energy efficiency policy initiatives since the 1970 s. The initiatives were originally aimed at energy security and reducing reliance on imports during the oil shocks of the 1970s. See Olivier Charnoz \& Ashwini Swain, High Returns, Low Attention, Slow Implementation: The Policy Paradoxes of India's Clean Energy Development 18 (Agence Française de Développement, Working Paper No. 125, 2012), available at http:/www.afd.fr/webdav/site/afd/shared/PUBLICATIONS/ RECHERCHE/Scientifiques/Documents-de-travail/125-document-travail-VA.pdf. The PAT program 
represent twenty-five percent of India's annual GDP, they represent forty-five percent of India's total energy consumption. ${ }^{91}$ The program is aimed primarily at reducing fuel imports and improving the international competitiveness of industry, not at greenhouse gas reductions. Nonetheless, the Ministry of Power estimated that between 2012 and 2015, the program would avoid ninety-eight million tons of greenhouse gas emissions that would otherwise have occurred. ${ }^{22}$

While the European programs aim to save fixed amounts of energy, India's program aims at energy efficiency, defined as energy consumed per unit of output by a firm. ${ }^{93}$ It does not guarantee any absolute level of energy savings.

Improvements in energy efficiency could be achieved through a number of policy instruments, including raising energy taxes or subsidizing plant upgrades. India instead opted for a market-based trading policy to address the so-called "bandwidth" problem in Indian industry. ${ }^{94}$ The bandwidth problem refers to the fact that some Indian industrial firms are highly energy efficient, among the top performing firms in the world in terms of energy consumption per unit of output. ${ }^{95}$ Other firms in the same industry lag far behind, using double or even triple the amount of energy per unit of output as the top performing plants. ${ }^{96}$ In fast-growing industries such as steel or concrete, these laggard, energy-hogging firms remain in business because aggregate demand for materials is growing so quickly in India. ${ }^{97}$ Every available plant therefore operates at capacity, despite wide differences in their cost structure and their consumption of

is an extension of earlier legislation, the Energy Policy Act of 2001, in which Parliament created a new Bureau of Energy Efficiency and mandated efficiency standards for appliances, energy consumption labeling, and energy audits of energy-intensive industries. See USAID, REPORT ON FINANCING ENERGY EFFICIENCY IN INDIA: A REVIEW OF CURRENT STATUS AND RECOMMENDATIONS FOR InNOVATIVE Mechanisms 17 (2013). Pre-existing law was crucial to the enactment of PAT. Since major industries in India were already subject to regular energy audits and reporting under the Energy Policy Act, PAT was seen as extension of existing law rather than a dramatic departure. See SANJAY DUBE ET AL., EMERGENT VENTURES INT'L, CAN THE LEARNINGS FROM INTERNATIONAL EXAMPLES

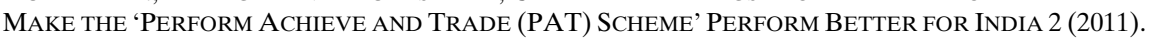

91. DUBE ET AL., supra note 90.

92. World BANK, InTERnAtional REVIEW OF TRADING SCHEMES FOR ENERGy SAVINGS AND CARBON EMISSIONS REDUCTIONS 40 (2013), available at https://www.thepmr.org/system/ files/documents/International \%20Review\%20of\%20Certificate \%20Trading $\% 20$ Schemes $\% 20$ v $\% 20 \mathrm{fi}$ nal\%20agreed.pdf.

93. Numerous studies have concluded that India has significant opportunities to use energy more efficiently as it builds out its housing, roads, industry, and other infrastructure in the next few decades. The Indian Ministry of Power has assessed the energy conservation potential of the economy at twenty-three percent, meaning that India could produce the same GDP with twenty-three percent less energy if it implemented policy and technological changes. EUR. Bus. \& TECH. CTR., ENERGY EFFICIENCY IN INDIA 2, http://www.ebtc.eu/pdf/111031_SNA_Snapshot_Energy-Efficiency-inIndia.pdf.

94. Albrecht Kaupp \& Shashi Shekhar, Let's Talk “Energy Efficiency + Energy Modesty", ECEEE 2003 SUMMER STUDY 221, 224, available at http://www.eceee.org/library/conference_ proceedings/eceee_Summer_Studies/2003c/Panel_1/1193kaupp.

95. Id. at 223 .

96. See id.

97. Ans Hariharasudhan, Construction Materials Market: Future Growth \& Demand Drivers, PROJECT VENDOR (Oct. 10, 2014), http://projectvendor.com/construction-materials-market-futuregrowth-demand-drivers. 
energy. Under PAT's trading structure, the marginal cost of efficiency upgrades is likely to vary widely, and the best-performing firms would be in a position to sell credits to the firms that operate antiquated plants.

Whether India can pull off this ambitious program is an open question..$^{98}$ PAT faces many of the same design challenges for an energy efficiency market that European nations face, and there are even greater transaction costs in the plant-by-plant measurement and verification system that is at the heart of the PAT program.

The mechanics are complex. For each of the 478 plants in the PAT program, the government set an energy efficiency target that the firm had to meet over the three-year period from 2012 to $2015 .^{99}$ The individual plant targets (from one to three percent per year) were established as a target improvement in efficiency compared to that plant's baseline energy efficiency, which was assessed over the three-year period from 2007 to $2010 .{ }^{100}$ In early 2015 , the energy consumption of each plant was measured to determine whether the plant surpassed its target and should be awarded ESCerts or whether the plant had fallen short of its target. ${ }^{101}$

In contrast to the European programs, with their off-the-shelf standardized set of efficiency upgrades, the PAT program is bespoke: each firm can customize the efficiency investments it wants to make within its own operations. There is no "deemed" energy savings from a standard menu of technological upgrades. Instead, the Indian plants can reach their targets through any mechanism they want, including equipment upgrades, changes in manufacturing processes, or fundamental changes to the plant. ${ }^{102}$ They can also choose not to make any changes and purchase ESCerts on the market instead. ${ }^{103}$ Compared to the European programs, PAT puts a much wider range of technologies and practices into play for achieving improvements in efficiency.

The drawback of this approach, however, is that the changes in energy consumption at each plant must be measured in the field, through $e x$ post auditing at the end of each program period, rather than the ex ante deemed savings approach. This is a substantial task for the 478 plants in the program, and this approach raises significant concerns about addi-

98. See Deepa Badrinarayana, The Kyoto Protocol's Emissions Trading Scheme: Realistic or Unjust Solution for Potential Developing Country Signatories?, 42 ENVT. L. REP. 11157, 11164 (questioning India's readiness and capability to implement market-based emissions trading domestically).

99. NeElam Singh, World Res. Inst., Creating Market Support FOR EnERgy EFFICIENCY: INDIA's PERFORM, ACHIEVE AND TRADE SCHEME 1-2 (2013), available at http://r4d. dfid.gov.uk/PDF/Outputs/CDKN/India-PAT_InsideStory.pdf.

100. Id. at 2; see also SAURABH DidDi, BurEAU OF ENERGy EFFICIENCY, MARKET BASED MECHANISM 13, https://www.thepmr.org/system/files/documents/India_Market_Mechanism_Promote _EE\%26Renewables.pdf.

101. See IN-2: Perform Achieve Trade Scheme (PAT Scheme), INDUS. EFFICIENCY POL'Y DATABASE, http://iepd.iipnetwork.org/policy/perform-achieve-trade-scheme-pat-scheme (last visited Aug. 29, 2016).

102. Rajesh Kumar \& Arun Agarwala, A Sustainable Energy Efficiency Solution in Power Plant by Implementation of Perform Achieve and Trade (PAT) Mechanism, 2 OPEN J. ENERGY EFFICIENCY 154, 154 (2013), available at http://file.scirp.org/pdf/OJEE_2013102514064939.pdf.

103. Id. at 159 . 
tionality - whether the program is crediting improvements in energy efficiency that would have occurred anyway at the plant. Moreover, the energy measurements at each plant will be conducted by a network of third-party auditors ${ }^{104}$ raising the possibility of corruption in the program. In India, corruption in environmental law enforcement is rampant. ${ }^{105}$ These monitoring and verification challenges will become even more complex if India follows through on plans to expand PAT to additional plants and industries.

\section{PRoblems of INSTITUTIONAL DESIGN IN ENERGY EFFICIENCY MARKETS}

As this discussion of the European and Indian programs suggests, energy efficiency markets are complex and require substantial governmental oversight to ensure that claimed energy savings have actually occurred. Under both the European model (covering energy suppliers and distributors) and the Indian model (covering energy end-users), it is clear that there are several hurdles to establishing effective, credible energy efficiency markets. The idealized vision of tradable permits, which predicts that trading will allow obligated firms to achieve an environmental goal at lower cost than traditional mandates, runs into several practical obstacles in the context of energy efficiency.

In this Part, I focus on three major problems of institutional design in energy efficiency markets: ensuring additionality, setting an environmentally meaningful savings target, and maintaining a system boundary. Together, these problems present a formidable set of challenges. They call into question the desirability of using tradable permits in this area of environmental law.

\section{A. The Problem of Ensuring Additionality}

The most pressing problem of institutional design is how to ensure additionality in energy efficiency markets - that is, how to award ESCerts only for real, verifiable energy savings that are additional to what firms would have achieved anyway in the absence of the programs. A failure to ensure additionality will undermine trust in the market by the public and by market participants, yet the transaction costs associated with accurately measuring energy savings are substantial. ${ }^{106}$ Failure to en-

104. Id. at $158-59$

105. See SAT Sharma, Corrupt InEPT RudDERless POliticians: IMPEDiments to India's MARCH FORWARD (2014); Michael Faure et al., Bucking the Kuznets Curve: Designing Effective Environmental Regulation in Developing Countries, 51 VA. J. INT'L L. 95, 99-100 (2010) ("Although countries such as India, Columbia, and Costa Rica have registered modest successes, environmental regulation in developing countries has remained a dead letter, unimplemented and unenforced."); M.C. Mehta, The Accountability Principle: Legal Solutions to Break Corruption's Impact on India's Environment, 21 J. ENVTL. L. \& LITIG. 141 (2006).

106. ENERGY SAVINGS CREDITS, supra note 39, at 31 (noting that the transaction costs associated with measuring energy savings have "certainly hampered the implementation of [energy efficiency] trading"). 
sure additionality also undermines the environmental goals of the program because in an ESCert market, firms that do not reach their energy savings or energy efficiency targets can purchase ESCerts to make up the difference. If those ESCerts, purporting to represent additional energy savings, were instead issued for energy savings that would have occurred anyway, then the trading program will actually weaken the underlying energy savings goals of the jurisdiction. ${ }^{107}$

Additionality in the context of ESCerts can be defined as "the certification of genuine and durable increases in the level of energy efficiency beyond what would have occurred in the absence of energy efficiency intervention." 108 To ensure additionality, regulators must avoid double counting efficiency improvements created by other programs (such as tax breaks for installing efficient appliances or other equipment), and they must also ensure that the ESCerts are additional to background improvements in energy efficiency being experienced in particular industries or in the economy as a whole. ${ }^{109}$

For several reasons, additionality is particularly difficult to ensure in energy efficiency markets. First, energy efficiency is often profitable. Even without ESCert programs, firms strive to reduce their energy consumption per unit of output for competitive reasons, and households and businesses similarly look for energy savings (such as installing compact fluorescent light bulbs or efficient air conditioners). ${ }^{110}$ To be sure, the level of energy efficiency investment is widely seen to be suboptimal, but even without ESCert trading programs, firms and households invest billions of dollars annually in equipment and practices that can reduce their fuel and electricity costs. ${ }^{111}$ If a regulator awards ESCerts for energy savings that the claimant would have pursued anyway, for its own reasons,

107. For further discussion of the role of additionality in market-based environmental policies, see Joe loper et al., Deal or No Deal? Pros and Cons of Trading Under an Energy

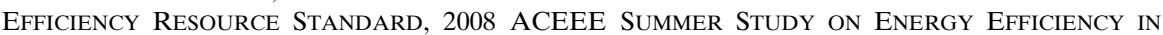
BlDGs. 5-183 (2008) [hereinafter DeAl or No Deal?]. See David M. Driesen, Choosing Environmental Instruments in a Transnational Context, 27 ECOLOGY L.Q. 1, 33-34 \& n.168 (2000) (noting that private parties' sale of credits for emissions reductions that they are required to make anyway under other laws could weaken performance of an emission trading program); Matthew Ranson \& Robert N. Stavins, Post-Durban Climate Policy Architecture Based on Linkage of Cap-and-Trade Systems, 13 CHI. J. INT'L L. 403, 409 (2013) (explaining that if regulated firms can purchase credits from emissions reduction projects that would have occurred anyway, aggregate emissions may increase or they may decrease to a lesser degree than in absence of such projects).

108. Tradable CertificATES, supra note 17, at 59; see also Mundaca, Markets for Energy Efficiency, supra note 15 , at 3021 .

109. As energy policy scholars Ole Langniss and Barbara Praetorius have explained, regulators must "take into account likely changes in relevant regulation and laws, the trend in autonomous efficiency improvements and changes of other basic variables such as the development of markets for products of the project ...." Langniss \& Praetorius, supra note 15, at 207 (internal citation omitted).

110. See Friedman et AL., supra note 32, at 8, 9, 12 (discussing the multiple reasons why firms strive to reduce their energy consumption); see also Carolyn Fischer, Project-based Mechanisms for Emissions Reductions: Balancing Trade-offs with Baselines, 33 ENERGY POL'Y 1807, 1808-09 (2005); Langniss \& Praetorius, supra note 15, at 208 (discussing the difficulty of determining whether energy consumption reduction would have occurred anyway).

111. In 2012, for example, global investments in energy efficiency were $\$ 310$ to $\$ 360$ billion. INT'L ENERgy Agency, ENERGy EFFICIENCY MARKet REPORT 2014: EXECUTIVE SuMmARY 1 (2014), available at $\mathrm{http} / / / \mathrm{www}$.iea.org/Textbase/npsum/EEMR2014SUM.pdf. 
then the regulator is granting a valuable credit that does not represent the true energy savings spurred by the program. ${ }^{112}$

Second, additionality is difficult to ensure in ESCert programs because there is a natural rate of improvement in energy efficiency over time due to technological advancement and productivity improvements. Energy consumed per unit of GDP has been declining throughout the developed world since the 1970s. ${ }^{113}$ Nations are getting better at producing goods and services with fewer energy inputs because of improvements in technology, a shift from heavy manufacturing to services, advances in materials science, changes in capital markets, more efficient motors and building design, and a host of other reasons. ${ }^{114}$ Energy consumption may decline in a utility's service area for a variety of reasons, including improvements in technology, better buildings, unusually warm winters, fluctuations in energy prices, or even a recession. ${ }^{115}$ Market participants, therefore, should be required to demonstrate that the energy savings they are claiming (even if accurately verified) have occurred because of the ESCert trading program rather than from these other "background" factors in the economy.

Third, some efficiency improvement occurs in industrial firms due to natural turnover of capital stock. Consider a steel manufacturing plant that replaces an outdated, 1970s boiler with a modern, efficient one, and therefore surpasses its government-set energy efficiency target under an ESCert program. In an energy efficiency market similar to PAT-one that focuses on energy end-users - the steel manufacturer may earn ESCerts worth hundreds of thousands of dollars. The additionality problem is that the boiler would have to be replaced at some point in the near future even in the absence of the program. There is a strong argument that the energy efficiency gain the firm has experienced is not additional, and an ESCert award would be an illegitimate "anyway" credit. ${ }^{116}$

112. See FRIEDMAN ET AL., supra note 32, at 22 (questioning public acceptance of ESCert programs because the programs involve firms undertaking energy efficiency upgrades to save money "and then turning around and selling the proof of that savings for yet more income.").

113. Howard Geller \& Sophie Attali, The Experience with Energy Efficiency Policies and Programmes in IEA countries: Learning from the Critics, INT'L ENERGY AGENCY, at 3 (2005), available at https://www.iea.org/publications/freepublications/publication/IEAEnergyPolicies_Learning_from_criti cs.pdf.

114. See generally Sebastian Voigt et al., Energy Intensity Developments in 40 Major Economies: Structural Change or Technology Improvement?, 41 ENERGY ECON. 47 (2014) (discussing reasons for the decline in energy intensity in major economies).

115. See Gilbert E. Metcalf, An Empirical Analysis of Energy Intensity and Its Determinants at the State Level, 29 ENERGY J. 1, 6-17 (2008) (studying energy consumption in forty-six U.S. states and discussing state-to-state variations in weather, income, and energy prices); see also Feng Song \& Xinye Zheng, What Drives the Change in China's Energy Intensity: Combining Decomposition Analysis and Econometric Analysis at the Provincial Level, 51 ENERGY P. 445, 449 (2012) (stating that variables in energy price, income, capital, investment, and urbanization influence differences in energy intensity in China's provinces).

116. See Michael Wara, Measuring the Clean Development Mechanism's Performance and Potential, 55 UCLA L. REV. 1759, 1797 (2008) (discussing "anyway" credits in the context of the Clean Development Mechanism). 
Finally, additionality is difficult to ensure because most countries have multiple policies and incentives in place to encourage household, commercial, and industrial efficiency. ${ }^{117}$ Common policies include tax credits, product subsidies, government procurement requirements, efficient building codes, and research and development subsidies. ${ }^{118}$ All of these policies affect the baseline against which the ESCert credit is being issued. So, for example, if a utility relies on ESCerts to reach its energy savings target, and the ESCerts were generated by installing insulation or highly efficient appliances in residences, the credit will not be additional if the homeowners would have likely installed the same insulation or appliances due to other policy incentives. ${ }^{119}$

In short, there are many reasons why an ESCert, purporting to represent energy savings achieved by a firm, may overestimate the savings and thereby undermine the credibility of the market. Lack of additionality has been the Achilles heel of other offset programs. ${ }^{120}$ The CDM, for example, has been heavily criticized for its failure to ensure additionality. Scholars have documented that project developers have gamed the system by obtaining credits for greenhouse gas reductions that probably would have occurred anyway. ${ }^{121}$ Michael Wara and David Victor showed, for example, that nearly all non-coal energy development projects in China received CDM credits, which makes sense only if one unrealistically assumes that no natural gas or renewable electricity generation would have been developed in China without the CDM credits. ${ }^{122}$ Another study of CDM projects in India concluded that while project developers did attempt to document additionality in their applications for credits, the auditing firms accredited by the CDM Executive Board simply took the applications at face value. They were not "able or willing to thoroughly check" that the claims of additionality had evidence to back them up. ${ }^{123}$

Compared to the scholarship on additionality in carbon markets, there has been far less scholarship on additionality in energy efficiency markets, but the programs appear equally vulnerable to double-counting and flawed estimation of credits. Just as in the CDM, neither the seller

117. See DEAL OR No DEAL?, supra note 107, at 5-190.

118. See id.

119. See Mundaca, Markets for Energy Efficiency, supra note 15, at 3020.

120. See Ruhl \& Salzman, supra note 25, at 46-49.

121. See Wara, supra note 116, at 1789 (describing gaming of the CDM and identifying it as a significant problem with the CDM market); Steven Ferrey, Cubing the Kyoto Protocol: Post-Copenhagen Regulatory Reforms to Reset the Global Thermostat, 28 UCLA J. ENVTL. L. \& POL'Y 343, 350 (2010) (stating that errors in verification of offsets, including those issued under the Clean Development Mechanism, represent a major disadvantage in the architecture of the Kyoto Protocol); McNish, supra note 31, at 391 (criticizing offset mechanisms such as the CDM).

122. Michael W. Wara \& David G. Victor, A Realistic Policy on International Carbon

Offsets 13-14 (Stanford Univ. Program on Energy and Sustainable Dev., Working Paper No. 74, 2008), available at $\mathrm{http}: / /$ iis-db.stanford.edu/pubs/22157/WP74_final_final.pdf.

123. Axel Michaelowa \& Pallav Purohit, Inst. For Political Sci., Univ. of Zurich, Discussion PAPER CDM-1, AdDitionAlity DETERMINATION OF INDIAN CDM PROJECTS: CAN INDIAN CDM PROJECT DEVELOPERS OUTWIT THE CDM EXECUTIVE BOARD? 13 (2007), available at http://climatestrategies.org/wp-content/uploads/2007/02/additionality-cdm-india-cs-version9-07.pdf. 
nor the buyer of an ESCert has any incentive to ensure that the credit represents real, verified, additional energy savings. ${ }^{124}$ The seller has an incentive to overstate energy savings to earn ESCerts, and the buyer, which is using the certificates for compliance purposes, would not typically care about the accuracy of the estimates used to generate the certificates. The market structure makes regulators the sole entity responsible for maintaining the integrity of the ESCerts. The probity of regulators (and third-party energy auditors) is all that stands between the integrity of the programs and the certification of bogus energy savings. ${ }^{125}$

Indeed, there are some signs that the existing energy efficiency markets in Europe and India are encountering additionality problems. The ex ante approach of the European programs, based on deemed savings, ostensibly simplifies energy savings accounting and crediting, but it does not avoid problems of additionality. The issue is that some of the energy savings that utilities are claiming for ESCerts would have occurred anyway. In Italy, for example, utilities have distributed millions of compact fluorescent light bulbs to their customers, earning ex ante credits for ESCerts. ${ }^{126}$ Many of these customers would have purchased these bulbs on their own, however, as consumers have done in the United States and elsewhere. ${ }^{127}$ Moreover, there is no verification in Italy to ensure that customers are actually using the bulbs that were distributed. ${ }^{128}$ In France, where utilities have earned ESCerts for installing efficient boilers, heat pumps, insulation, and windows for their customers, those same items are also eligible for homeowner tax credits. ${ }^{129}$ Homeowners may have ultimately undertaken these projects anyway, even without utility funding or assistance. A comprehensive review of the programs in Europe concluded that the additionality of the efficiency projects used to generate ESCerts "has not been clear." 130

India's PAT market is also prone to double-counting and additionality problems. Because the ESCerts are issued on an ex post basis, at the end of each program cycle, it may seem that regulators would be well positioned to ensure that energy savings have actually materialized. But there is no attempt in the PAT program to document what portion of a

124. See McNish, supra note 31 , at 428 .

125. Id.

126. See Where to Place the Saving Obligation, supra note 41, at 331.

127. See Joe loper et al., Alliance to Save Energy, Scaling-Up Energy Efficiency Programs: The MeAsurement Challenge 12-14 (2010), available at http://www.ase.org/sites/ase. org/files/energy_measurement_challenge_0.pdf.

128. See Silvia Rezessy \& PaOlo Bertoldi, Energy Supplier Obligations and White Certificate Schemes: Comparative AnAlysis of Results In the European Union, 2010 ACEEE SUMMER STUDY ON ENERGY EFFICIENCY IN BLDGS. 8-308 (2010) ("[T]he extent to which the CFLs are actually used remains unclear and hence the actual amount of savings achieved in reality.").

129. See id. at 8-305. See also GIRAUDET \& FINON, supra note 17, at 14 ("[F]or many energy efficiency measures [in France] . . . the same invoice can be used by customers to claim for a fiscal subsidy and by obliged suppliers to claim for white certificates."); id. at 22 ("In France, the specific effect of the scheme on technology diffusion is difficult to isolate, because of the overlap with the tax credit scheme.").

130. BERTOLDI \& REZESSY, supra note 49, at 308. 
firm's improvement in energy efficiency is due to the program and what portion would have occurred anyway due to background improvements in the technology or other factors discussed above. Energy auditors instead simply assess each regulated plant's energy consumption at the beginning and the end of each program cycle and divide the total energy consumed by the plant's output to get a measure of improvements in energy efficiency. ${ }^{131}$ The additionality problem is that regulators will award ESCerts to plants that surpass their target, even though some improvement in efficiency would likely have occurred anyway. ${ }^{132}$

\section{B. The Problem of Setting the Energy Savings Target}

The second major problem with the design of energy efficiency markets is that the energy savings targets (or energy efficiency targets) have been unambitious, closely paralleling what industries and utilities were achieving on their own. If the targets are too lax, then ESCert trading prices will remain low and the program will hardly be worth the effort. The largest potential advantage of ESCert programs is that they allow trading among firms with different marginal costs of compliance, reducing the overall cost of achieving energy savings. But that advantage disappears if the target is too lax and all firms have essentially the same marginal costs of compliance.

Scholars of market-based instruments in environmental law have paid insufficient attention to this central issue of target setting. ${ }^{133}$ The emphasis in the literature is on the trading aspect of these programs, rather than on the initial governmental responsibility of setting the program's target. ${ }^{134}$ But the government-established target is at the core of most market-based environmental policies. The target determines the ultimate ambition and environmental results of the program. The target determines the scarcity of the traded good and therefore its selling price. From the standpoint of the environment, the stringency of the energy savings target matters far more than the trading aspects of these programs. ${ }^{135}$

In energy efficiency markets established to date, regulators have often set weak energy savings or efficiency targets that fail to establish scarcity in the market for ESCerts. The unambitious targets instead approximate business-as-usual improvements in energy efficiency. In India, for example, the PAT program aimed for overall $5.8 \%$ gains in energy

131. See SINGH, supra note 99 , at 2 .

132. See S. P. Garnaik, Bureau of Energy Efficiency, Perform, Achieve \& Trade (PAT), BEE EXPERIENCE 12, available at www.iipnetwork.org/PAT-ppt_BEE\%20Doc\%209.pdf (last visited Aug. 29, 2016).

133. See The Overallocation Problem, supra note 25, at 398 ("Remarkably, there is little written on the topic of how caps in cap-and-trade programs should be set.").

134. See David M. Driesen, Capping Carbon, 40 EnvTl L. 1, 11 (2010) [hereinafter Capping Carbon] (describing a "vast economic literature on emissions trading that said little or nothing about setting caps, focusing instead on the effects of allowing trading.").

135. See id. at 4-5. 
efficiency in the eight covered industries over three years, between 2012 and 2015, but the energy efficiency of Indian industry was already improving at an annual rate of $1.5 \%$ before PAT took effect. ${ }^{136}$ The PAT targets were only slightly more stringent than what Indian industries had been achieving, on average, on their own.

To be sure, regulators could increase target stringency over time, but there are a variety of political pressures that tend to militate against more ambitious target setting. Indeed, lax targets in these programs are not an aberration. Rather, they reflect a larger trend of over-allocation and insufficient stringency in many market-based policies in environmental law.

In cap-and-trade programs, for example, Leslie McAllister has documented numerous examples of weak caps that require little change in behavior from regulated industries, drawing examples from the U.S. acid-rain program, California's RECLAIM program, and the European Emissions Trading System ("ETS"). ${ }^{137}$ Weak caps lead to a lack of scarcity in the market for the tradable permit or allowance, and there is a correspondingly weak price signal for firms to change their behavior. Because of weak caps in the ETS, for example, allowance prices have remained below seven euros per ton of carbon dioxide for over two years, ${ }^{138}$ far below expectations, and the ETS is now widely derided as "lifeless" 139 and "moribund." ${ }^{140}$ With weak program targets, the supposed advantages of market-based policies in environmental law evaporate. Without a strong price signal, for example, the market will fail to incentivize deep reductions in pollution, and regulated firms will make "few, if any, emissions reductions from business-as-usual emissions." ${ }^{141}$ Moreover, lax program targets and weak price signals will fail to spur the technology innovation that is touted as one of the primary benefits of market-based approaches to environmental law. ${ }^{142}$

What explains the pattern of weak caps and program targets in multiple market-based environmental programs? The most likely explanation is that the weak caps and targets reflect the politics of enacting and overseeing these programs. To launch a market-based environmental program and win industry cooperation for its passage, the focus is often on the expected private costs of the program rather than the environ-

136. See GARNIAK, supra note 132.

137. See The Overallocation Problem, supra note 25, at 398-410.

138. For historical trends in EU ETS allowance prices, see Carbon Emissions Futures, INVESTING.COM, http:/www.investing.com/commodities/carbon-emissions-streaming-chart (last visited Aug. 29, 2016).

139. Christian Oliver \& Pilita Clark, EU Plans to Revive Lifeless Carbon Market, FIN. TIMES (Oct. 13, 2014, 8:10 AM), http://www.ft.com/intl/cms/s/0/23d2b622-4fce-11e4-a0a4-00144feab7de.html\# axzz45UFR9FAn.

140. EU Trading Market Collapses, Coal Cheap as Dirt, GlobE \& MAIL (Apr. 17, 2013), http:// www.theglobeandmail.com/report-on-business/rob-commentary/executive-insight/eu-carbon-tradingcollapses-coal-cheap-as-dirt/article11311111/.

141. The Overallocation Problem, supra note 25, at 397.

142. See Driesen, supra note 24, at 436 (arguing that cap-and-trade provides few, if any, incentives for expensive technological innovation); Taylor, supra note 24, at 4804. 
mental goals. ${ }^{143}$ Therefore, regulators have an incentive to enact weak program targets to lower the overall cost for industry. Moreover, in capand-trade programs, regulated industries tend to lobby for weak caps that ensure that allowance prices will remain reasonable even if demand for the allowances runs high. If this high demand scenario does not actually materialize, however, the program ends up over-allocating allowances, with corresponding low prices and limited environmental effectiveness. ${ }^{144}$

Another explanation for the pattern of weak program targets in market-based environmental policies is that the targets reflect cautious judgments by regulators about the technical feasibility for firms to reach the target. In setting a target for a market-based program, regulators must ask themselves: how much improvement can we realistically require of regulated firms? This judgment is inevitably shaped by the state of available technology, by politics, and by the need to get continuing cooperation from firms for the program.

Market advocates frequently claim that market-based instruments obviate the need for regulators to make these kinds of decisions about technological feasibility. ${ }^{145}$ Nearly thirty years ago, Richard Stewart and Bruce Ackerman argued that emissions trading avoids the defects inherent in having regulators set technology-based pollution control standards for individual facilities, a task that they claimed involves massive information gathering challenges and adversarial contests over the appropriate standard. ${ }^{146}$ Stewart and Ackerman's view - that market-based policies avoid the need for regulators to set technology-based standards-has since become conventional wisdom. ${ }^{147}$

Market proponents overlook, however, that in setting the appropriate cap or target for a market-based environmental program, regulators are confronted with decisions on technological feasibility that are similar to those they face in enacting traditional, prescriptive environmental

143. See McAllister, The Overallocation Problem, supra note 25, at 426

144. See id. at 436

145. See, e.g., Bruce Ackerman \& Richard Stewart, Comment, Reforming Environmental Law, 37 STAN. L. REV. 1333, 1336-37, 1342 (1985) (noting that the tradable permit system they propose would eliminate "most of the information-processing tasks [involving technology-based standards] that are presently overwhelming federal and state bureaucracies.").

146. Bruce Ackerman \& Richard Stewart, Reforming Environmental Law: The Democratic Case for Market Incentives, 13 COLUM. J. ENVTL. L. 171, 179 (1988).

147. See e.g., Neil GunNingham ET Al., SMART Regulation: Designing EnVIRONMENTAL POLICY 39n.5 (1998) (noting the problems with technology-based regulation and arguing that agencies cause "technolog[y] lock-in" through regulation); Adam Babich, Understanding the New Era of Enviornmental Law, 41 S.C. L. REV. 733 (1990) (challenging the premises of "command and control" regulation and discussing market-based alternatives); Robert W. Hahn \& Gordon L. Hester, Marketable Permits: Lessons for Theory and Practice, 16 Ecology L.Q. 361 (1989); Andrew P. Moriss et al., Principles for Water, 15 TUL. ENVTL. L.J. 335 (2002) (arguing for the superiority of market-based approaches to water law); Richard Stewart, Models for Environmental Regulation: Central Planning Versus Market-Based Approaches, 19 B.C. ENVTL. AFF. L. REV. 547 (1992) (arguing for the use of marketbased incentives rather than "command-and-control regulation"); Cass R. Sunstein, Congress, Constitutional Moments, and the Cost-Benefit State, 48 STAN. L. REV. 247, 260 (1996) (arguing that technology-based mandates provide little incentive for innovation). 
regulations. ${ }^{148}$ Indeed, as David Driesen has explained, because regulators develop emissions trading programs with close attention to the level of environmental improvement that is technologically and economically feasible for firms, "emissions trading often becomes a form of [technology-based regulation], rather than an alternative to it." ${ }^{149}$ Market-based environmental policies do provide firms with flexibility to decide how they will achieve an environmental goal, but market-based policies do not avoid the central problem that regulators face in enacting any new environmental program: deciding how much environmental improvement can feasibly be demanded, in aggregate, from the regulated firms.

In ESCert trading markets, target setting is complex and politically fraught for regulators. Should regulators require utilities to achieve a six percent reduction in energy consumption in their service areas over five years, or a ten or fifteen percent reduction? What would happen if the target is too strict and ESCerts trade at a price that begins to become noticeable on customer bills? Evidence suggests that regulators are reluctant to set ambitious targets for ESCert trading markets and often require business-as-usual reductions in energy consumption, or some small additional percentage just beyond business as usual. ${ }^{150}$ These small, incremental steps limit the potential of energy efficiency markets to make a substantial contribution to climate change goals.

Target-setting in energy efficiency markets becomes particularly complex if regulators go beyond setting broad energy savings goals for a region or an industry to setting narrowly tailored goals for individual facilities. In India's PAT Program, for example, many firms protested that a single numeric target for improvement in energy efficiency for a given industry would be unfair because it would penalize early movers. ${ }^{151}$ That is, facilities that had already made significant investments in energy efficiency would be asked to make the same percentage improvement in energy efficiency as antiquated, poorly-performing plants. In response to this concern, the Bureau of Energy Efficiency agreed to set individual energy efficiency improvement targets for each of the 478 plants in the program, a task that added greatly to the complexity of the program. ${ }^{152}$

The need for individuation in target setting suggests how complicated target-setting could become if energy efficiency markets were ex-

148. See Emissions Trading, supra note 67, at 329 (noting that market mechanisms raise "the usual issues that arise in a traditional regulation, such as how costly reductions will be, how much benefit they will yield, and whether they are technologically achievable.”).

149. Capping Carbon, supra note 134, at 6.

150. See ENERGY SAVINGS CREDITS, supra note 39, at 24, 26 (noting that many states in the U.S. have established energy savings mandates for utilities that "do not drive energy savings significantly beyond business-as-usual" and that a significant increase in these mandates would make them "politically less palatable").

151. Piyush Verma et al., India's Initiatives on Improving Energy Efficiency in Aluminium Industries, 1 ASIA-PAC. J. ENERGY \& ENV’T 215, 217 (2014).

152. CTR. FOR CleAN AIR POLICY, BALANCING ENERGY EFFICIENCY AND INDUSTRIAL Growth: A MARKET-BASED, GROWTH-FrIENDLY SOLUTION 2 (2012), available at http://ccap. org/assets/CCAP-Booklet_India_PAT.pdf; Gerard Wynn, Markets Can Boost Energy Efficiency Projects, ARAB NEws (Sept. 3, 2012) www.arabnews.com/markets-can-boost-energy-efficiency-projects. 
panded to thousands of actors in various industries, as many advocates have championed. To deploy tradable ESCerts as a tool for energy efficiency across a whole economy, regulators would need to determine reasonable, technologically feasible energy savings targets for thousands of individual facilities. They would then need to measure and verify energy consumption at those facilities and reward those facilities that surpass their target. This is a mammoth undertaking on a national scale.

\section{The Problem of Defining the System Boundary}

A final problem with establishing markets for energy efficiency is defining the system boundary-the question of how regulators should define the geographic boundary of a participating firm, region, or facility.

In any environmental regulatory program, there is the potential that regulated firms in the jurisdiction will choose to relocate outside the jurisdiction. There is also a risk that non-regulated firms outside the jurisdiction will gain a competitive advantage vis-à-vis regulated firms in the jurisdiction. The issue of geographic boundaries is particularly pressing in climate-change programs because of the global nature of the problem. If major sources of greenhouse gas emissions react to one jurisdiction's climate-mitigation policies by relocating outside the geographic boundaries of regulation - the problem of "carbon leakage" - then the enacting jurisdiction's environmental goals will be severely undermined. ${ }^{153}$ The greenhouse gases will simply be emitted outside the boundary of regulation.

Energy efficiency markets are prone to a similar problem, which I call "energy savings leakage." The issue is that energy savings ostensibly achieved in one location may prove to be ephemeral because energyintensive activities have simply relocated elsewhere, leading to no net reduction in energy consumption. Energy savings leakage has not been well explored in the existing literature on ESCert markets, but it could be a significant limitation on the scope of the programs, and further empirical research is necessary to document the scope of the problem.

In an ESCert trading program, the extent of energy savings leakage depends on the design of the market. Leakage is not likely to be significant under the European model of energy efficiency markets, where a limited number of energy suppliers and distributors conduct efficiency upgrades in residential and commercial facilities. The programs are national in scope, and it is unlikely that a utility would relocate its business simply because of new energy savings mandates. Any utility that finds it expensive to perform energy efficiency upgrades will simply purchase

153. InT'L ENERgy AgenCy, Issues Behind COMPETITIVENESS AND CARBON LEAKAGE 3 (2008) (defining carbon leakage as "the ratio of emissions increase from a specific sector outside the country (as a result of a policy affecting that sector in the country) over the emission reductions in the sector.”); Gilbert E. Metcalf \& David Weisbach, The Design of a Carbon Tax, 33 HARV. ENVTL. L. Rev. 499, 503 (2009); Neil Peretz, Carbon Leakage Under the European Union Emissions Trading Scheme: Is It A Major Policy Concern?, 23 TUL. ENVTL. L.J. 57, 60 (2009). 
ESCerts and pay any penalty, rather than fundamentally adjust its business operations.

Energy savings leakage could become a significant problem, however, under energy efficiency markets like India's PAT program, where energy end-users are expected to make efficiency upgrades within their own operations. The concern is that firms could achieve improvements in energy efficiency and earn valuable ESCerts by outsourcing their energyintensive operations to other firms that are not regulated in the market. A textile plant, for example, could improve its energy efficiency simply by outsourcing its dyeing operation elsewhere. The plant would show the same annual output of textiles with far lower energy consumption, suggesting that it has improved its energy efficiency, even though in reality it has simply outsourced part of its operation.

Because this model of an energy efficiency market measures energy consumption within the fence-line of a particular facility, it is all too easy to game the system: simply contract out, wherever possible, the energy intensive parts of a production line..$^{154}$ If this is done after the firm's baseline energy efficiency has already been measured, then any firm can make it appear that it has achieved dramatic improvements in energy efficiency. ${ }^{155}$

Market enthusiasts are overlooking this important structural constraint on the energy efficiency markets: it matters a great deal how regulators define the "facility" to be measured. ${ }^{156}$ If, as advocates suggest, thousands of entities could participate in a single market by seeking out opportunities to save energy and selling those energy savings to other participants, the problem of defining the "facility" to be measured and monitored becomes intractable. What would it mean to claim that a certain industry, plant, or building has achieved energy savings compared to some baseline? How would regulators delineate the boundary of the facility to be measured? With dynamic economies, low-cost shipping, and an infinite ability for any facility to contract out operations, the accounting challenge is clear. Simply measuring the amount of energy that has been consumed within some physical perimeter is insufficient. To maintain a credible system boundary in an energy efficiency market, regulators would need to monitor not only how much energy was used by a facility at the beginning and end of a program period, but also the process

154. See Ruhl \& Salzman, supra note 25, at 46 (exploring ways that baseline-credit systems can be "gamed" to the advantage of regulated entities).

155. Taylor, supra note 24, at 4804 (noting that carbon leakage can also occur if "policymakers ... may decide to count emissions reductions in uncapped areas or economic sectors as "offsets' for unrealized emissions reductions within a capped region or sector.").

156. India has adopted a "gate-to-gate" accounting concept that examines efficiency improvements within the physical perimeter of the plant. See Rajesh Kumar \& Arun Agarwala, A Sustainable Energy Efficiency Solution in Power Plant by Implementation of Perform Achieve and Trade (PAT) Mechanism, 2 OPEN J. ENERGY EFFICIENCY 154, 157 (2013), available at http://file.scirp.org/ pdf/OJEE_2013102514064939.pdf (discussing the gate-to-gate concept and the definition of plant boundaries). Gate-to-gate accounting simplifies measurement of energy consumption, but it cannot account for changes in operations in which energy-intensive parts of a plant's operations are outsourced to other firms that are outside the perimeter of the facility being measured. 
changes that occurred within the facility during that period. This increases both the intrusiveness of the programs and governmental monitoring costs.

\section{CONCLUSION}

Improving energy efficiency is critical for reducing greenhouse gas emissions, but as this Article demonstrates, policymakers seeking to harness tradable permits for energy efficiency goals face a number of challenging obstacles. Energy efficiency markets are complex - an "elaborate instrument" 157 that requires substantial government oversight - and they are hampered by persistent problems of measurement and verification. As a tool for climate change mitigation, the markets established to date have had only modest results. Although governments have been experimenting with energy efficiency markets for a decade, the markets remain operational in only a few countries, and they have not made a significant impact on the greenhouse gas emissions profiles of the countries that have adopted them. India's Perform Achieve Trade program is a new policy with substantially different parameters from the European programs, and it remains to be seen whether India's model-a national energy efficiency trading market involving industrial firms-can achieve verified improvements in energy efficiency with acceptable transaction costs.

The experience with energy efficiency markets underscores that tradable permits are not a panacea for achieving environmental goals. Indeed, if the programs are poorly designed, without adequate attention to verification and additionality, tradable permits can actually undermine environmental goals by allowing firms to avoid required environmental improvements by purchasing credits that do not represent real environmental improvements elsewhere. Tradable permits, moreover, do not avoid the need for regulators to make difficult choices on technological feasibility, target setting, and maintaining system boundaries.

The problems identified in this Article should not detract from the importance of improving energy efficiency to address climate change. Numerous studies have identified energy efficiency as one of the cheapest way to mitigate greenhouse gas emissions. ${ }^{158}$ The policy toolbox to improve energy efficiency includes many approaches, including information disclosure, government procurement, building codes, vehicle standards, energy taxes, and utility demand response programs. Tradable permit programs are not an essential part of the energy efficiency policy mix.

157. Nicholas Labanca \& Adriaan Perrels, Editorial: Tradable White Certificates - A Promising but Tricky Policy Instrument, 1 ENERGY EFFICIENCY 233 (2008).

158. See, e.g., InT'L ENERgy Agency, CAPturing the Multiple Benefits of ENergy EFFICIENCY 18 (2014); MCKINSEY \& Co., supra note 9, at 2; RUSSELl ET AL., ACEEE, RECOGNIZING THE VALUE OF ENERGY EFFICIENCY's MULTIPLE BENEFITS 12-14 (2015). 
